\title{
PENINGKATAN STABILITAS KURKUMIN MELALUI PEMBENTUKAN KOMPLEKS KURKUMIN- $\beta$-SIKLODEKSTRIN NANOPARTIKEL DALAM BENTUK GEL
}

\section{STABILITY ENHANCEMENT OF CURCUMIN BY FORMULATING CURCUMIN-B-CYCLODEXTRIN NANOPARTICLE GEL}

\author{
Citra Ariani Edityaningrum $^{1}$, Heni Rachmawati ${ }^{2}$ \\ ${ }^{1}$ Fakultas Farmasi Universitas Ahmad Dahlan \\ Jl. Prof. Dr. Soepomo, Janturan, Yogyakarta, Telp. (0274) 379418 \\ ${ }^{2}$ Fakultas Farmasi Institut Teknologi Bandung, Bandung \\ Email: citra.arianie@gmail.com
}

\begin{abstract}
ABSTRAK
Kurkumin merupakan senyawa yang salah satunya terdapat pada rhizoma tanaman.Senyawa ini praktis tidak larut dalam air dan memiliki stabilitas yang rendah pada $\mathrm{pH}$ fisiologis termasuk kulit.Untuk meningkatkan stabilitas kurkumin yang dibuat dalam sediaan gel untuk penghantaran transdermal, dengan pembentukan kompleks inklusi dengan senyawa $\beta$-siklodekstrin dan pengecilan ukuran partikel menjadi berukuran nanometer. Kompleks inklusi telah dibuat pada penelitian sebelumnya dengan metode freeze drying dan dari hasil karakterisasi menunjukkan adanya interaksi antara kurkumin dan $\beta$-siklodekstrin membentuk kompleks inklusi. Formula tersebut menghasilkan ukuran partikel 156,8 $\pm 38,3 \mathrm{~nm}$, indeks polidispersitas $0,174 \pm 0,026$, zeta potensial $-17,3 \pm 0,2 \mathrm{mV}$. Selanjutnya, pada penelitian ini dilakukan optimasi basis gel dengan menggunakan beberapa gelling agent yaitu HPMC, CMC-Na, karbopol 940, karboksimetil kitosan, dan viscolam. Gelling agent terbaik adalah viscolam, dimana menghasilkan viskositas dan $\mathrm{pH}$ gel stabil selama penyimpanan 28 hari pada suhu 25 dan $40^{\circ} \mathrm{C}$. Viscolam kemudian digunakan sebagai basis gel kompleks inklusi dan kurkumin.Hasil yang didapat yaitu kedua gel memiliki viskositas dan $\mathrm{pH}$ yang stabil selama penyimpanan, dan terjadi peningkatan stabilitas kadar kurkumin dari gel kompleks inklusi sekitar 2,12 kali $(\mathrm{p}<0,01)$ pada suhu $25^{\circ} \mathrm{C}$, dan 1,41 kali $(\mathrm{p}<0,05)$ pada suhu $40{ }^{\circ} \mathrm{C}$ dibanding gel kurkumin tanpa inklusi.
\end{abstract}

Kata kunci: Kurkumin, $\beta$-siklodekstrin, nanopartikel, gel, stabilitas

\begin{abstract}
Curcumin is a compound derived from turmeric. This compound is practically insoluble in water and has poor stability. To improve the benefit of curcumin as a potential active compound in a gel preparation, better stability are requested. Encapsulation was performed by freeze drying methods and all evaluation data confirmed that curcumin included in the $\beta$-cyclodextrin forming curcumin- $\beta$ cyclodextrin nanoparticle. The formula showed particle size of $156.8 \pm 38.3 \mathrm{~nm}$, polydispersity index of $0.174 \pm 0.026$, and zeta potential of $-17.3 \pm 0.2 \mathrm{mV}$. The gelling agents used for formulation of gel base were HPMC, CMC-Na, carbopol 940, water-soluble chitosan, and viscolam. Viscolam showed best stability of $\mathrm{pH}$ and viscosity after storage at 25 and $40{ }^{\circ} \mathrm{C}$ for 28 days. The inclusion complex and curcumin were incorporated into gel. Both of the formulas showed good stability in $\mathrm{pH}$ and viscosity after storage at 25 and $40^{\circ} \mathrm{C}$ for 28 days, and the inclusion complex gel showed improvement in the chemical stability which is approximately 2.12 -fold $(\mathrm{p}<0.01)$ and 1.41 -fold $(\mathrm{p}<0.05)$, after storage at 25 and $40{ }^{\circ} \mathrm{C}$, respectively.
\end{abstract}

Keywords: curcumin, $\beta$-cyclodextrin, gel, nanoparticle, stability 


\section{PENDAHULUAN}

Kurkumin merupakan senyawa polifenolik hidrofobik yang salah satunya terdapat pada rhizoma tanaman Curcuma longa Linn. Senyawa ini memiliki aktivitas farmakologi yang luas seperti antiinflamasi,anti mutagenik, anti oksidan, anti kanker (Maheswari dkk., 2006), anti mikroba (De dkk., 2009), dan anti parasit (Shahiduzzaman dan Daugschies, 2011). Senyawa ini terbukti memiliki aktivitas antiinflamasi (Majeed dkk.,1995) dan bersifat selektif menghambat COX-2 (Zhang dkk., 1999).Oleh karena itu, kurkumin merupakan senyawa potensial sebagai agen antiinflamasi yang lebih aman dibandingkan Obat Antiinflamasi Non Steroid (OAINS)yang bersifat non selektif, seperti ibuprofen dan piroksikam, yang memiliki efek samping gastrointestinal seperti perforasi, perdarahan lambung dan duodenal, dispepsia, serta nyeri abdomen (Vane dan Botting, 1996).

Akan tetapi, kurkumin memiliki kelarutan yang rendah di dalam air $(\approx 20 \mu \mathrm{g} / \mathrm{mL}$ pada suhu $25^{\circ} \mathrm{C}$ ) dan memiliki stabilitas yang buruk yaitu cepat terdegradasi pada $\mathrm{pH} 6$ sekitar $16 \%$ dan pada $\mathrm{pH} 6,5$ sekitar $23 \%$ dalam waktu 2 jam pada suhu $37^{\circ} \mathrm{C}$ (Wang, 1996). Kedua hal tersebut menyebabkan bioavailabilitas sistemik kurkumin rendah baik jika digunakan per oral maupun transdermal. Selain itu, jika digunakan per oral, kurkumin dapat mengalami first pass metabolism di hati dan intestin, dimana kurkumin diubah menjadi metabolit yang inaktif. Hal ini menyebabkan kurkumin cepat dieliminasi dari tubuh, sehingga pemberian oral kurkumin menjadi tidak efektif (Anand dkk., 2007).

Keterbatasan penggunaan kurkumin dengan rute oral mendorong peneliti melakukan pendekatan alternatif dalam bentuk sediaan topikal gel dengan rute transdermal untuk meningkatkan efikasi kurkumin. Selain itu, sediaan gel mudah diaplikasikan pada kulit apabila terjadi inflamasi, memberikan efek dingin karena penguapan lambat dari kulit, pelepasan obatnya baik, dan mudah dicuci dengan air. Kurkumin yang memiliki kelarutan rendah dalam air terlebih dahulu harus ditingkatkan laju pelarutannya agar dapat dibuat sediaan gel. Usaha peningkatan laju pelarutan kurkumin sudah dilakukan melalui pembentukan kompleks inklusi dengan senyawa $\beta$-siklodekstrin dan pengecilan ukuran partikel menjadi berukuran nanometer (Rachmawati, dkk., 2013), sehingga kurkumin menjadi mudah dibuat dalam sediaan gel. Melalui pembentukan kompleks inklusi dengan $\beta$-siklodekstrin dan dalam bentuk gel diharapkan pula dapat terjadi peningkatan stabilitas kurkumin terhadap pH kulit (6-6,5). Peningkatan stabilitas tersebut diharapkan terjadi karena molekul kurkumin terlindungi di dalam rongga $\beta$-siklodekstrin. Pada penelitian ini diuji stabilitas gel kompleks inklusi kurkumin- $\beta$ siklodekstrin dibandingkan dengan gel kurkumin tanpa inklusi. Penelitian ini diharapkan dapat menghasilkan sediaan topikal kurkumin nanopartikel yang stabil secara fisik dan kimia sehingga potensial untuk dikembangkan dalam skala produksi sebagai produk komersial.

\section{METODE PENELITIAN}

\section{Bahan Penelitian}

Kurkumin (PT. Phytochemindo Lestari), $\beta$-siklodekstrin (PT. Sanbe Farma), aseton pro analisis (Merck), aqua deion, aquabidest (Ippha Laboratories), HPMC (Brataco), CMC-Na (Brataco), karbopol 940 (Brataco), karboksimetil kitosan, viscolam (Nardev Chem), gliserin (Brataco), propilen glikol (Brataco), metil paraben (Brataco), propil paraben (Brataco), asetonitril pro analisis (J. T. Baker), trietanolamin dimetilsulfoksid (DMSO) (Merck).

\section{Jalannya Penelitian}

\section{Pembuatan kompleks inklusi kurkumin- $\beta$-siklodekstrin}

Pembuatan kompleks inklusi dilakukan dengan metode freeze drying. Sejumlah $200 \mathrm{mg}$ serbuk $\beta$-siklodekstrin dilarutkan dalam aqua deion hingga terlarut. Sejumlah 20\% kurkumin dilarutkan dalam $2 \mathrm{~mL}$ aseton pro analisis hingga terlarut. Kedua larutan tersebut dicampur, disonikasi selama 5 menit, dan diaduk menggunakan magnetic stirrer selama 5 jam dengan kecepatan $200 \mathrm{rpm}$ tanpa tutup untuk menguapkan aseton. Campuran bahan kemudian disentrifugasi selama 15 menit dan kecepatan 3000 rpm. Supernatan yang mengandung 
kompleks inklusi nanopartikel diambil, dan disaring menggunakan filter $0,45 \mu \mathrm{m}$. Kemudian dilakukan freeze drying $\left(-35^{\circ} \mathrm{C}, 0,01\right.$ Torr $)$, dan disimpan pada suhu $4^{\circ} \mathrm{C}$ hingga penggunaan berikutnya (Rachmawati, dkk., 2013).

\section{Optimasi basis gel}

Optimasi basis gel dilakukan dengan menggunakan variasi jenis gelling agent (tanpa kurkumin). Komposisi basis gel dan bahan pembantu dapat dilihat pada Tabel I. F1, F2, dan F3 dibuat dengan cara HPMC/ CMC-Na/ karboksimetil kitosan didispersikan dalam air suling panas $\left(80^{\circ} \mathrm{C}\right)$, dan khusus untuk HPMC perlu didiamkan selama 24 jam. Setelah itu ditambahkan sisa air dan dilakukan pengadukan menggunakan stirrer dengan kecepatan 500 rpm selama 10 menit. Selanjutnya ditambahkan bahan pembantu lain dan diaduk dengan kecepatan 500 rpm selama 5 menit.

F4 dan F5 dibuat dengan cara karbopol 940 atau viscolam didispersikan dalam air suling, dan dan khusus untuk F4 didiamkan selama 24 jam. Kemudian diaduk menggunakan stirrer dengan kecepatan 500 rpm selama 10 menit, ditambahkan bahan pembantu lain dan diaduk kembali dengan kecepatan $500 \mathrm{rpm}$ selama 5 menit.

Setelah itu dilakukan adjustment $\mathrm{pH}$ dengan penambahan TEA hingga diperoleh basis yang kental dan $\mathrm{pH}$ berkisar 6-7. Pengadukan dilakukan dengan kecepatan $500 \mathrm{rpm}$ selama 5 menit agar homogen. Masing-masing gel disimpan pada suhu kamar (suhu $25^{\circ} \mathrm{C}$ ) dan pada climatic chamber (suhu $40^{\circ} \mathrm{C}$, RH $75 \pm 5 \%$ ) selama 28 hari. Evaluasi dilakukan untuk mencari basis gel terbaik, yaitu dengan pengukuran $\mathrm{pH}$ dan viskositas basis gel dalam interval waktu tertentu. Pengukuran dilakukan pada hari ke- 0,4 , $7,15,18,22,25$, dan 28.

\section{Pengembangan formula gel kurkumin dan kompleks inklusi}

Setelah diperoleh basis optimum, dilakukan pembuatan gel kompleks inklusi kurkumin- $\beta$-siklodekstrin nanopartikel dan gel kurkumin yang masing-masing menggunakan zat aktif kurkumin 0,01 (\%b/b). Pembuatan gel kurkumin dilakukan dengan mencampur kurkumin dengan bahan pembantu terlebih dahulu, kemudian ditambahkan ke dalam basis gel. Gel kompleks inklusi kurkumin- $\beta$ siklodekstrin dibuat dengan cara kompleks inklusi dilarutkan dengan air suling, kemudian dicampur dengan basis gel, dan dibuat sesuai prosedur pembuatan basis gel yang optimal.

\section{Uji stabilitas sediaan gel}

Uji stabilitas sediaan gel dilakukan untuk gel kurkumin dan gel kompleks inklusi kurkumin- $\beta$-siklodekstrin. Kedua gel disimpan pada suhu kamar (suhu $25^{\circ} \mathrm{C}$ ) dan pada climatic chamber (suhu $40^{\circ} \mathrm{C}$, RH $75 \pm 5 \%$ ) selama 28 hari. Evaluasi dilakukan pada hari ke-0, 4, 7, 15, $18,22,25$, dan 28, yang meliputi:

Tabel I. Optimasi basis gel dengan variasi gelling agent

\begin{tabular}{lccccc}
\hline \multicolumn{1}{c}{ Bahan } & $\mathbf{F 1}$ & $\mathbf{F 2}$ & $\mathbf{F 3}$ & $\mathbf{F 4}$ & $\mathbf{F 5}$ \\
& $(\boldsymbol{\%} \mathbf{b} / \mathbf{b})$ & $(\boldsymbol{\%} \mathbf{b} / \mathbf{b})$ & $(\boldsymbol{\%} \mathbf{b} / \mathbf{b})$ & $(\boldsymbol{\%} \mathbf{b} / \mathbf{b})$ & $(\boldsymbol{\%} \mathbf{b} / \mathbf{b})$ \\
\hline HPMC & 2 & - & - & - & - \\
CMC-Na & - & 2 & - & - & - \\
Karboksimetil kitosan & - & - & 10 & - & - \\
Karbopol 940 & - & - & - & 1 & - \\
Viscolam & - & - & - & - & 5 \\
Metil paraben & 0,2 & 0,2 & 0,2 & 0,2 & 0,2 \\
Propil paraben & 0,05 & 0,05 & 0,05 & 0,05 & 0,05 \\
Gliserin & 5 & 5 & 5 & 5 & 5 \\
Propilen glikol & 15 & 15 & 15 & 15 & 15 \\
Air suling hingga & 100 & 100 & 100 & 100 & 100 \\
\hline
\end{tabular}


a. Pengamatan Organoleptik

Pengamatan organoleptik sediaan gel meliputi kejernihan, perubahan warna, bau, pertumbuhan mikroba selama penyimpanan, dan penerimaan pada kulit.

b. Pengukuran $\mathrm{pH}$ dan Viskositas

Pengukuran $\mathrm{pH}$ sediaan gel dilakukan menggunakan $\mathrm{pH}$ meter. Uji viskositas dilakukan menggunakan viskometer Brookfield dengan kecepatan $5 \mathrm{rpm}$.

c. Pengukuran Kadar

Pengukuran kadar kurkumin dalam kedua sediaan gel dilakukan dengan HPLC kolom Phenomenex ${ }^{\circledR}$ Luna $\mathrm{C}_{18}$ dengan ukuran partikel $5 \mu \mathrm{m}$ dan diameter internal $250 \mathrm{~mm} \mathrm{x}$ 4,6 mm; pada panjang gelombang $425 \mathrm{~nm}$. Fase gerak yang digunakan adalah asetonitril dan dapar fosfat $0,045 \mathrm{M} \mathrm{pH} 4,5$ dengan perbandingan 55:45 (v/v). Laju alir yang digunakan sebesar $1 \mathrm{~mL} /$ menit dan volume sampel $50 \mu \mathrm{L}$. Sebelumnya, dilakukan ekstraksi kurkumin dari dalam gel dengan cara gel dilarutkan dengan fase gerak sambil diaduk dengan vortex. Sebelum diinjeksikan, sampel disaring menggunakan filter $0,2 \mu \mathrm{m}$. Kurva kalibrasi dibuat menggunakan larutan baku kurkumin dengan rentang konsentrasi $1,25-10 \mathrm{ppm}$.

\section{HASIL DAN PEMBAHASAN}

Pada penelitian sebelumnya telah dilakukan upaya peningkatan laju pelarutan kurkumin dalam air melalui pembentukan kompleks inklusi antara kurkumin dengan $\beta$ siklodekstrin dengan metode freeze drying (Rachmawati dkk., 2013). Peningkatan laju pelarutan kurkumin dalam air penting agar kurkumin mudah dibuat dalam basis gel yang hidrofilik. Dengan metode tersebut dihasilkan formula kurkumin- $\beta$-siklodekstrin-nanopartikel dengan ukuran partikel $156,8 \pm 38,3 \mathrm{~nm}$ dan indeks polidispersitas $0,174 \pm 0,026$ yang menunjukkan distribusi ukuran partikelnya homogen. Kompleks inklusi tersebut kemudian dibuat dalam bentuk gel. Formulasi gel diawali dengan pemilihan basis gel dengan kriteria memiliki $\mathrm{pH}$ dan viskositas yang stabil dimana tidak terpengaruh oleh perubahan suhu pada saat penyimpanan. Di samping itu, basis gel yang dipilih adalah yang memiliki penampilan transparan dengan aliran baik, dan penerimaan di kulit yang nyaman.

Pada penelitian ini digunakan lima variasi bahan pembentuk gel yaitu HPMC, CMC$\mathrm{Na}$, karboksimetil kitosan, karbopol 940, dan viscolam. Masing-masing bahan tersebut telah dioptimasi sehingga didapatkan konsentrasi terbaik, dimana dicari konsentrasi terendah yang masih dapat membentuk masa gel yang baik dan stabil. Masing-masing basis gel dibuat sebanyak tiga vial dan disimpan pada suhu kamar (suhu 25 ${ }^{\circ} \mathrm{C}$ ) dan pada climatic chamber (suhu $40{ }^{\circ} \mathrm{C}, \mathrm{RH}$ $75 \pm 5 \%$ ) selama 28 hari. Pada interval waktu tertentu, semua basis gel diukur $\mathrm{pH}$ dan viskositasnya dengan hasil yang digambarkan pada Gambar 1 dan 2.

Hasil pengukuran viskositas basis gel karbopol tidak digambarkan pada grafik karena pada titik ketiga (hari ke-7) viskositas sudah tidak dapat terukur (terlalu viskos). Adapun hasil pengukuran basis gel karbopol pada suhu $25{ }^{\circ} \mathrm{C}$ dan suhu $40{ }^{\circ} \mathrm{C}$ berturut-turut adalah: titik I. $63233,33 \pm 4760,60 ; 66600 \pm 8303,21$; dan titik II. $45133,33 \pm 5518,45 ; 38833,33 \pm 9500,70$ cps.

Dari Gambar 1 terlihat viskositas basis gel viscolam paling stabil setelah disimpan 28 hari pada kedua suhu.Hanya bahan HPMC, CMC-Na, dan viscolam yang memberikan viskositas yang cukup baik di mana dapat mengalir sehingga mudah dituang. Akan tetapi setelah disimpan selama 28 hari, viskositas basis gel HPMC, CMC-Na, dan juga kitosan naik turun (tidak stabil).

Ketika dioleskan di kulit, seluruh bahan memberikan rasa lembut, kecuali basis gel karboksimetil kitosan yang mengelupas sehingga memberikan rasa kasar di kulit. Hal tersebut dikarenakan karboksimetil kitosan merupakan polimer yang dapat membentuk lapisan film. Jika dioleskan di kulit, karboksimetil kitosan membentuk lapisan film yang mudah mengelupas sehingga nantinya jika digunakan dengan penambahan zat aktif, basis gel akan hilang sebelum zat aktif masuk ke dalam kulit. Oleh karena itu, karboksimetil kitosan tidak terpilih sebagai basis gel yang baik. Seluruh basis gel 
memberikan penampilan yang jernih selain karbopol dan karboksimetil kitosan yang keruh. Basis HPMC terlihat jernih, namun ketika dicoba dicampur dengan kompleks inklusi menjadi keruh. Hal ini dapat dikarenakan gugus hidroksipropil pada HPMC dapat meningkatkan aktivitas permukaan dari senyawa ini (Gaonkar, 1991) mengakibatkan ketidakstabilan dari sistem kompleks inklusi. Oleh karena itu, kurkumin menjadi keluar dari sistem dan menyebabkan kekeruhan.Berdasarkan keseluruhan pengujian terhadap basis gel, didapat basis gel viscolam yang terbaik karena memiliki $\mathrm{pH}$ dan viskositas baik dan stabil, penampilan jernih, serta memberikan rasa lembut di kulit. Dari grafik stabilitas $\mathrm{pH}$ basis gel pada Gambar 2, $\mathrm{pH}$ basis gel viscolam juga tampak lebih stabil dibanding bahan lainnya selama interval waktu tersebut.

a)

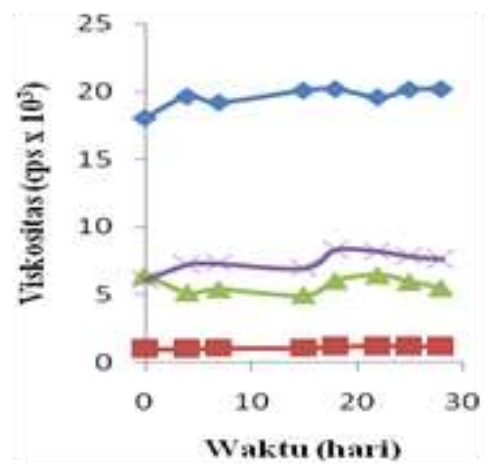

Berdasarkan keseluruhan pengujian terhadap basis gel, didapat basis gel viscolam yang terbaik karena memiliki $\mathrm{pH}$ dan viskositas baik dan stabil, penampilan jernih, serta memberikan rasa lembut di kulit. Basis gel terbaik, yaitu viscolam, digunakan dalam pembuatan gel kompleks inklusi kurkumin- $\beta$ siklodekstrin nanopartikel dan gel kurkumin dengan komposisi kurkumin masing-masing sebesar $0,01(\% \mathrm{~b} / \mathrm{b})$. Dari hasil pengukuran viskositas selama 28 hari (Gambar 3), viskositas semua gel stabil dan dapat mengalirsehingga mudah dituang, serta memiliki $\mathrm{pH}$ yang stabil (Gambar 4). Berdasarkan perhitungan dengan $t$ student berpasangan $(\mathrm{p}>0,05)$, tidak terdapat perbedaan secara bermakna baik viskositas maupun $\mathrm{pH}$ masing-masing gel pada hari ke-0 dan hari ke-28, pada suhu 25 dan $40{ }^{\circ} \mathrm{C}$.

\section{Gambar 1. Profil stabilitas viskositas basis gel pada: a) suhu $25^{\circ} \mathrm{C}$, dan b) suhu $40{ }^{\circ} \mathrm{C}$}

a)

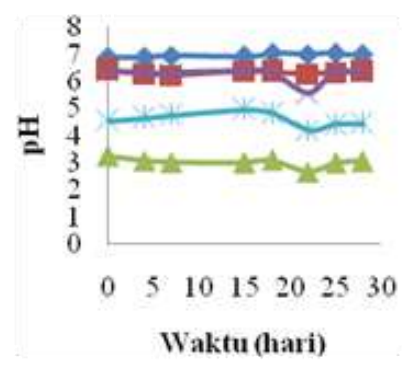

Waktu (hari) b)

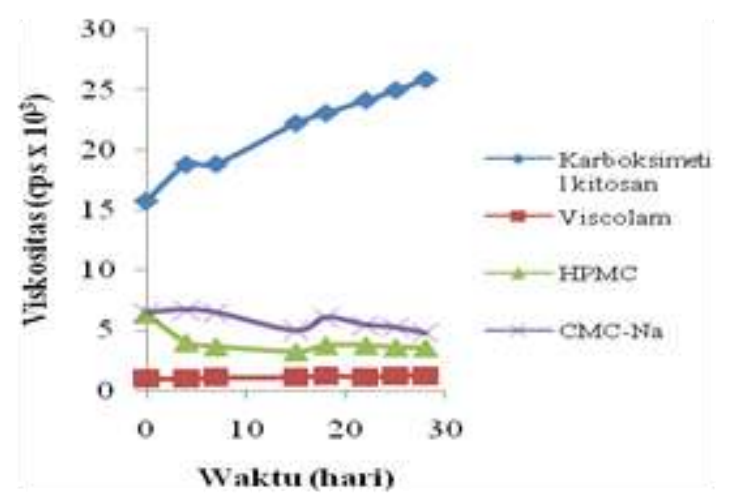

b)

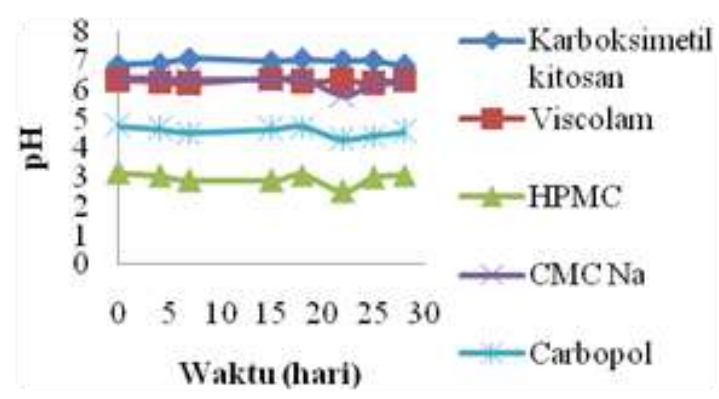

Gambar 2. Profil stabilitas pH basis gel pada: a) suhu $25^{\circ} \mathrm{C}$, dan b) suhu $40{ }^{\circ} \mathrm{C}$ 
a)

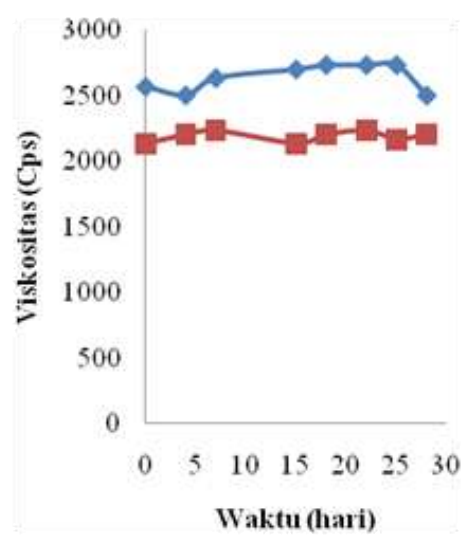

b)

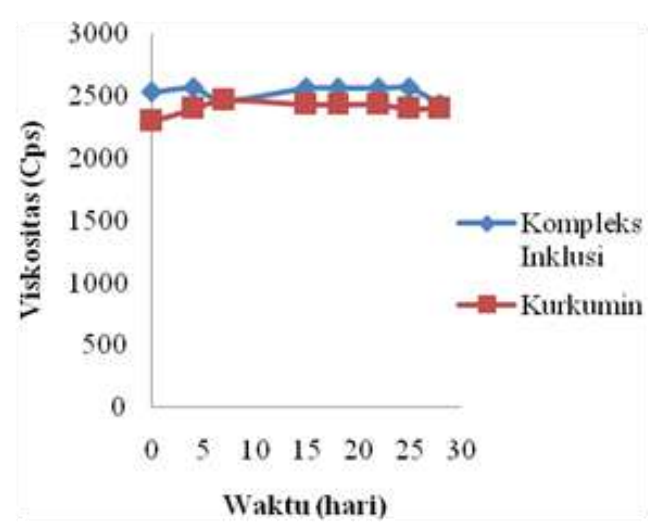

Gambar 3. Profil stabilitas viskositas gel pada: a) suhu $25^{\circ} \mathrm{C}$, dan b) suhu $40{ }^{\circ} \mathrm{C}$

a)

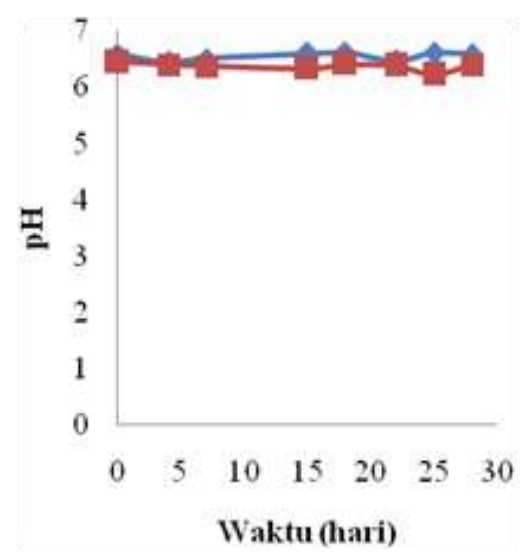

b)

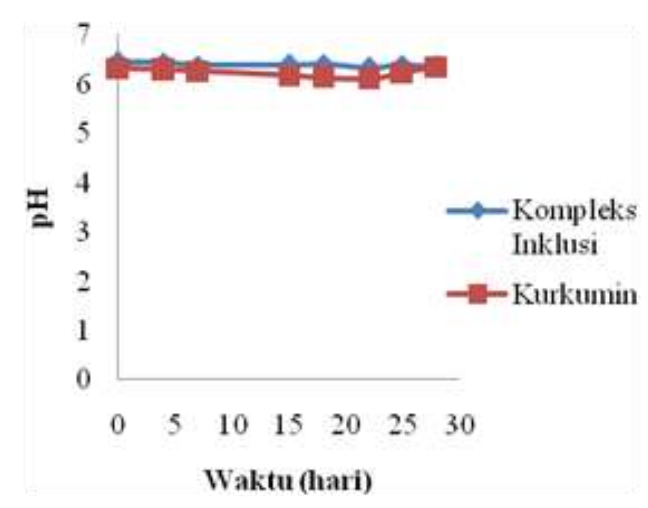

Gambar 4. Profil stabilitas pH gel pada: a) suhu $25{ }^{\circ} \mathrm{C}$, dan b) suhu $40{ }^{\circ} \mathrm{C}$

a)

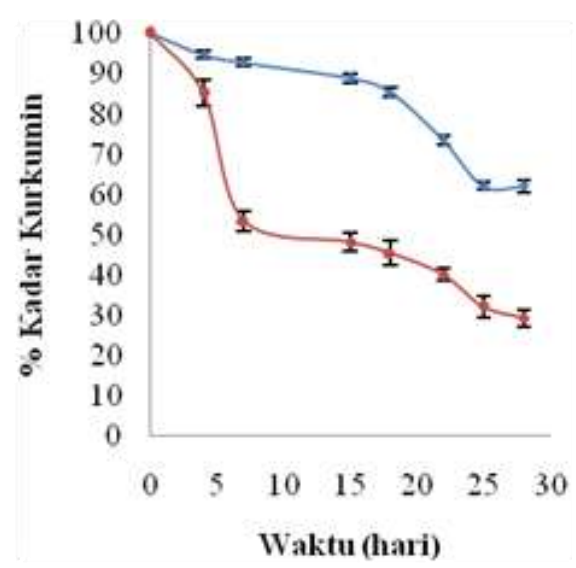

b)

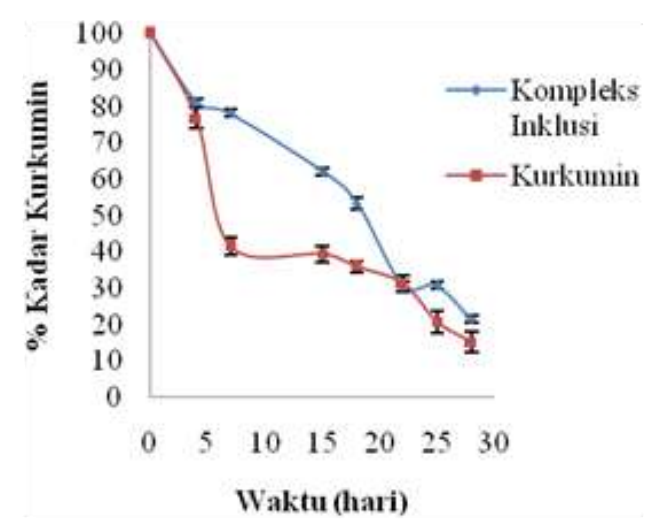

Gambar 5. Profil stabilitas kadar kurkumin pada gel kompleks inklusi dan gel kurkumin pada suhu: a) $25^{\circ} \mathrm{C}$, dan b) $40{ }^{\circ} \mathrm{C}$ 


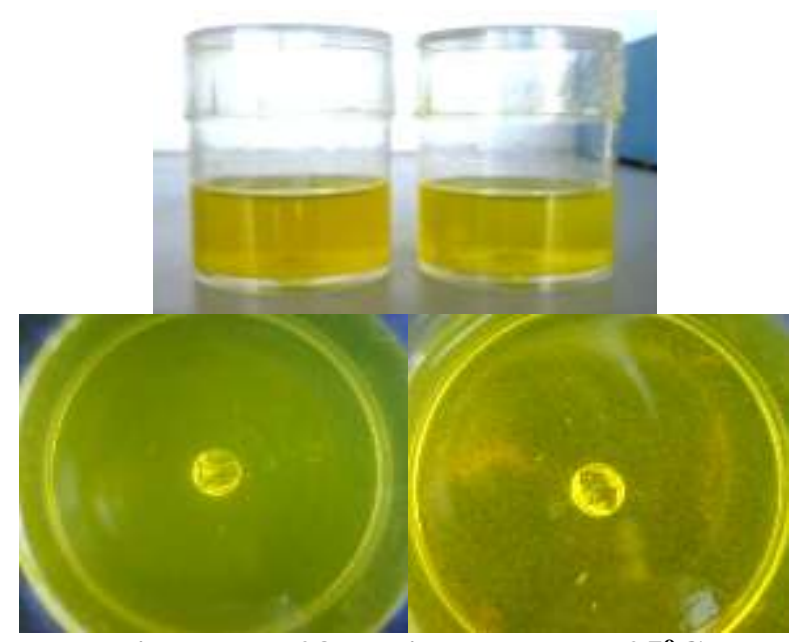

Gambar 6. Foto setelah penyimpanan 28 hari pada suhu $25^{\circ} \mathrm{C}$; gel kompleks inklusi jernih (kiri) dan pada gel kurkumin telah terbentuk endapan (kanan)

Pada penelitian Wang dkk. (1996) diketahui pada $\mathrm{pH} 6$ kurkumin terdegradasi sekitar $16 \%$ dan pada $\mathrm{pH} 6,5$ sekitar $23 \%$ dalam waktu 2 jam pada suhu $37{ }^{\circ} \mathrm{C}$. Oleh karena itu, dalam penelitian ini diteliti pengaruh formulasi sediaan gel kompleks inklusi kurkumin- $\beta$ siklodekstrin terhadap stabilitas kurkumin pada pH sediaan sekitar 6-6,5. Kadar kurkumin pada gel kompleks inklusi ditentukan tiap rentang waktu tertentu dan dibandingkan dengan kadar kurkumin pada gel kurkumin. Kadar kurkumin diukur menggunakan HPLC dengan detektor UVVisible pada $\lambda 425 \mathrm{~nm}$.

Gambar 5 menunjukan penurunan kadar kurkumin dari kedua sediaan gel pada penyimpanan di suhu 25 dan $40{ }^{\circ} \mathrm{C}$ selama 28 hari. Penurunan kadar ini diduga karena kurkumin terdegradasi seperti pada penelitian Wang dkk. (1996). Berdasarkan analisis statistik menggunakan $t$-student tidak berpasangan, terdapat perbedaan secara bermakna antara kadar akhir yang didapat dari pengukuran sampel gel kompleks inklusi dibanding gel kurkumin. Dari hasil ini diketahui terjadi peningkatan stabilitas kadar kurkumin pada gel kompleks inklusi yaitu sebesar 2,12 kali $(\mathrm{p}<0,01)$ pada suhu $25{ }^{\circ} \mathrm{C}$, dan 1,41 kali $(\mathrm{p}<0,05)$ pada suhu $40{ }^{\circ} \mathrm{C}$. Hal tersebut menandakan melalui pembentukan kompleks inklusi dapat meningkatkan stabilitas kimia kurkumin dalam gel selama penyimpanan. Jadi, $\beta$-siklodekstrin diketahui kurang dapat melindungi kurkumin pada suhu $40^{\circ} \mathrm{C}$.
Formula gel kompleks inklusi kurkumin$\beta$-siklodekstrin yang dihasilkan jernih hingga akhir penyimpanan. Hal ini menandakan bahwa kelarutan kurkumin- $\beta$-siklodekstrin tetap terjaga dengan baik. Lain halnya dengan formula gel kurkumin, dimana terjadi presipitasi pada hari ke5 dan 7, masing-masing berturut-turut pada suhu 40 dan $25^{\circ} \mathrm{C}$. Dari hasil tersebut, diketahui dengan pembentukan kompleks inklusi kurkumin- $\beta$-siklodekstrin dapat meningkatkan stabilitas fisik kurkumin dalam sediaan gel. Gambar 6 memperlihatkan gel kompleks inklusi dan kurkumin setelah penyimpanan 28 hari pada suhu $25{ }^{\circ} \mathrm{C}$, dimana serupa dengan hasil pada suhu $40{ }^{\circ} \mathrm{C}$.

\section{KESIMPULAN}

Kompleks inklusi kurkumin- $\beta$ siklodekstrin nanopartikel dalam sediaan gel memberikan peningkatan stabilitas fisik dan kimia kurkumin sebesar 2,12 ( $\mathrm{p}<0,01)$ dan 1,41 kali $(\mathrm{p}<0,05)$ berturut-turut pada pada suhu $25^{\circ} \mathrm{C}$ dan $40{ }^{\circ} \mathrm{C}$ dibanding gel kurkumin tanpa inklusi.

\section{UCAPAN TERIMA KASIH}

Penulis ingin mengucapkan terima kasih kepada Indonesia Managing High Education for Relevance and Efficiency (IM-HERE) Program, dari Institut Teknologi Bandung, yang telah membiayai penuh penelitian ini. 


\section{DAFTAR PUSTAKA}

Anand, P., Kunnumakkara, A.B., Newman, R.A., dan Aggarwal, B.B., 2007, Bioavailability of Curcumin: Problems and Promises, Molecular Pharmacology. 4 (6) : 807-818.

De, R., Kundu, P., Swarnakar, S., Ramamurthy, T., Chowdhury, A., Nair, G.B., dan Mukhopadhyay, A.K., 2009, Antimicrobial Activity of Curcumin Against Helicobacter pylori Isolates from India and During Infections in Mice, Antimicrob. Agents Chemother. 53 (4):1592-7.

Gaonkar, A.G., 1991,Surface and Interfacial Activities and Emulsion Characteristics of Some Food Hydrocolloids, Food Hydrocolloid. 5(4):329-337.

Maheswari, R.K., Singh, A.K., Gaddipati, J., dan Srimal, R.C., 2006, Multiple Biological Activities of Curcumin: a Short Review, Life Sci.78 (18):2081-7.

Majeed, M., Badmaev, V., Shivakumar, U., dan Rajendran, R. 1995.Curcuminoids Antioxidant Phytonutrients. Nutriscience Publisher. New Jersey, 44-50.

Rachmawati, H., Edityaningrum, C.A., dan Mauludin, R., 2013, Molecular Inclusion Complex of Curcumin- $\beta$-Cyclodextrin
Nanoparticle to Enhance Curcumin Skin Permeability from Hydrophilic Matrix Gel, AAPS PharmSciTech.14(4):1303-12. DOI: 10.1208/s12249-013-0023-5.

Shahiduzzaman, M.D., dan Daugschies, A., 2011, Curcumin: A Natural Herb Extract with Antiparasitic Properties, Parasitology Research Monographs.1:141-152.

Vane, J.R. and Botting, R.M., 1996, Overview Mechanism of Action of Antiinflammatory Drugs, in Improved Nonsteroid Anti-inflammatory Drugs COX-2 Enzyme Inhibitors, Edited by Sir John Vane, Jack Botting and Regma Botting, Kluwer Academic Publishers and William Harvey Press, Great Britain, 103-119.

Wang, Y.J., Pan, M.H., Cheng, A.L., Lin, L.I., Ho, Y.S., Hsieh, C.Y., dan Lin, J.K., 1996, Stability of Curcumin in Buffer Solutions and Characterization of Its Degradation Products, J. Pharm. Biomed. Anal. 15 (12):1867-1876.

Zhang, F., Altorki, N.K., Mestre, J.R., Subbaramaiah, K., dan Dannenberg, A.J., 1999, Curcumin Inhibits Cyclooxygenase-2 Transcription in Bile Acid- and Phorbol Ester Treated Human Gastrointestinal Epithelia Cells, Carcinogenesis.20:445-451. 